Buana Sains Vol 20 No 1: 99 - 110, 2020

\title{
REVIEW : \\ PENGARUH PEMANASAN GLOBAL TERHADAP INTENSITAS SERANGAN KUTU KEBUL (Bemisia tabbaci Genn ) DAN CARA PENGENDALIANNYA PADA TANAMAN KEDELAI
}

\author{
I Made Indra Agastya, Reza Prakoso Dwi Julianto dan Marwoto \\ Fakultas Pertanian, Universitas Tribhuwana Tunggadewi, Indonesia
}

\begin{abstract}
Global warming has changed global, regional and local climate conditions. Global climate change is caused, among others, by the increase in greenhouse gas emissions (GHG) due to various activities that drive the increase in the earth's temperature. Given that climate is a key element in the metabolic system, plant physiology and crop ecosystems, global climate change will adversely affect the sustainability of agricultural development. The impact of global climate change is the increasing population of pests on agricultural crops. One of the soybean pests whose population is increasing due to the increase in air temperature is the Bemisia tabbaci infestation. Increased pest populations of Bemesia tabbaci infestation in soybean crops cause dwarf leaves of dwarf plants and threatens to increase soybean production. Efforts to overcome the impact of global warming is mainly due to increased pest populations, it is necessary to think and seek breakthroughs to anticipate the explosion of pest populations in soybean crops, among others by: the optimization of natural control, physical and mechanical control and cultivation techniques. The combination of techniques or tactics of the optimal component of soybean pest control technology is established on the basis of appropriate information knowledge about soybean pest, ecosystem and socio-economic based on IPM approach.
\end{abstract}

Keywords: Bemisia tabbaci; control; global warming; pest; soybean.

\section{Pendahuluan}

Kedelai memiliki posisi strategis dalam ketahanan pangan sebagai sumber protein nabati, dan bahan makanan fungsional (functional food) bermutu tinggi bagi kesehatan manusia yang selama ini terjangkau oleh masyarakat luas. Produk olahan kedelai seperti tempe, tahu, susu kedelai, kecap, keripik dan sebagainya diperlukan setiap hari sepanjang tahun bagi seluruh masyarakat. Untuk mencukupi kebutuhan industri olahan tersebut, Indonesia membutuhkan kedelai sekitar 2,2 juta ton per tahun. Sementara, produksi kedelai dalam negeri dewasa ini 960 ribu ton, hanya mampu memenuhi sekitar $30-40 \%$ dari kebutuhan nasional.

Salah satu kendala utama dalam peningkatan produksi kedelai adalah karena gangguan hama. Kerugian akibat serangan hama pada tanaman kedelai dapat menurunkan hasil sampai $80 \%$, bahkan puso apabila tidak ada tindakan pengendalian (Marwoto, 2007). Tanaman kedelai sangat disukai oleh hama dan penyakit, terbukti dengan banyaknya 
hama yang menyerang yakni hama dalam tanah, hama bibit, hama daun, hama penggerek batang, dan hama polong kedelai.

Pemanasan global telah mengubah kondisi iklim global, regional dan lokal. Perubahan iklim global disebabkan antara lain oleh peningkatan emisi Gas Rumah Kaca (GRK) akibat berbagai aktivitas yang mendorong peningkatan suhu bumi. Mengingat iklim adalah unsur utama dalam sistem metabolisme, fisiologi tanaman dan ekosistem tanaman, maka perubahan iklim global akan berdampak buruk terhadap keberlanjutan pengembangan pertanian. Salah satu dampak perubahan iklim global adalah meningkatnya populasi hama pada tanaman pertanian. Tanaman kedelai di negara tropis termasuk Indonesia mempunyai kompleksitas hama yang beragam, dengan adanya peningkatan suhu di bumi akan berakibat juga meningkatnya populasi hama pada tanaman kedelai. Hama kedelai yang populasinya meningkat akibat kenaikkan suhu udara, salah satunya adalah hama kutu kebul Bemisia tabaci. Meningkatnya populasi hama kutu kebul pada pertanaman kedelai menyebabkan daun keriting tanaman kerdil dan akan mengancam peningkatan produksi kedelai.

Upaya untuk mengatasi meningkatnya populasi hama kutu kebul B. tabaci, akibat dari dampak pemanasan global diperlukan pemikiran dan mencari terobosan-terobosan untuk mengantisipasinya. Bukan hanya pada sumber penyebab terjadinya perubahan iklim, tetapi juga penanggulangan dan tindakan apa yang harus kita persiapkan jika perubahan iklim itu terjadi. Tujuannya adalah menyadarkan kita untuk proaktif dalam upaya untuk mengatasi atau memperkecil dampak peningkatan populasi hama kutu kebul $B$. tabbaci akibat perubahan iklim global.

\section{Hasil dan Pembahasan}

\section{Kerusakan Tanaman Akibat Serangan Kutu Kebul}

Secara umum serangan Bemisia spp pada tanaman, ada tiga macam kerugian yang dapat di akibatkan oleh hama ini, yaitu : 1) kerusakan secara langsung, 2) kerusakan secara tidak langsung dan 3) perannya sebagai vektor penyakit virus. Kerusakan secara langsung disebabkan oleh hama ini adalah hama secara langsung menusuk dan menghisap cairan floem tanaman inang, akibatnya tanaman menjadi layu, pertumbuhan terhambat dan produktivitas menurun. Selain itu, kehilangan cairan menyebabkan daun mengalami klorosis, mudah remuk, gugur sebelum waktunya, hingga akhirnya tanaman mati. Kerusakan secara tidak langsung yang di akibatkan oleh serangan Bemisia spp. adalah adanya akumulasi embun madu yang diproduksi oleh nimfanya. Ekskreta kutu kebul menghasilkan embun madu yang merupakan medium tumbuh cendawan jelaga, sehingga tanaman sering tampak berwarna hitam. Embun madu sangat potensial sebagai media pertumbuhan cendawan embun jelaga seperti: Cladosporium spp. dan Alternaria spp. Hal ini dapat menyebabkan proses fotosintesa pada tanaman kedelai tidak normal (Tengkano dan Suhardjan, 1985).

Kerusakan tanaman oleh Bemisia spp sebagai vektor virus, selain merusak tanaman secara langsung juga sebagai serangga vektor virus yang dapat menularkan penyakit Cowpea Mild Mottle Virus (CMMV) 
pada kedelai dan kacang-kacangan lain. Di Jawa Timur terdapat enam strain virus yang menyerang tanaman kedelai dan CPMMV merupakan salah satu yang di tularkan oleh Bemisia spp. Infeksi virus pada tanaman kedelai pada umumnya menghasilkan gejala yang serupa yakni klorosis, belang dan mosaik pada daun, daun keriput sehingga sulit dibedakan (Saleh dan Hardaningsih, 2007).

Serangan kutu kebul yang parah akan menyebabkan tanaman kerdil, daun keriput dan polong hampa. Ketahanan varietas unggul terhadap serangan kutu kebul beragam. Varietas unggul kedelai Anjasmoro termasuk varietas yang sangat peka terhadap serangan kutu kebul (Marwoto, 2010). Pola tingkat serangan kutu kebul pada pertanaman kedelai relatif sama pada setiap musim (MK I dan MK II) hanya saja varietas memberikan tanggapan yang beragam terhadap serangan kutu kebul (Gambar 1). Penggunaan varietas yang berbeda berpengaruh nyata terhadap intensitas serangan kutu kebul. Varietas Anjasmoro menunjukkan intensitas serangan yang paling tinggi

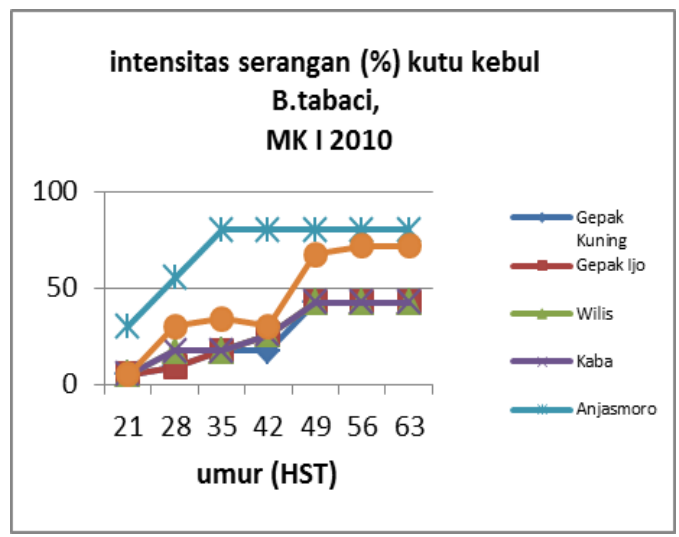

a baik pada MK I (80\%) maupun MK II $(63,67 \%)$. Varietas Anjasmoro yang merupakan hasil seleksi masa dari keturunan galur murni Mansuria pada penelitian ini merupakan varietas yang paling rentan terhadap kutu kebul. Varietas Anjasmoro yang terserang kutu kebul menunjukkan pertumbuhan yang terhambat, yaitu tanaman menjadi kerdil, daun berwana hijau tua dan penuh ditutupi embun jelaga berwarna hitam serta polong yang dihasilkan sangat sedikit dan abnormal. Hasil pengamatan terhadap populasi hama kutu kebul pada berbagai varietas tidak menunjukkan perbedaan, tetapi menunjukkan intensitas serangan yang berbeda pada berbagai varietas yang diteliti (Gambar 1). Hal ini dikarenakan varietas Anjasmoro peka terhadap serangan virus tanaman kedelai, dengan melihat gajala serangan daun keriting dan tanaman kerdil. Kutu kebul disamping sebagai hama tanaman juga sebagai serangga hama pembawa virus. Kutu kebul mampu menularkan penyakit CMMV, MYMV dan SCLV (Kameya, 2001). Pada tanaman kedelai di Jawa hanya penyakit CMMV yang dapat dideteksi (Hirano et al., 1993).

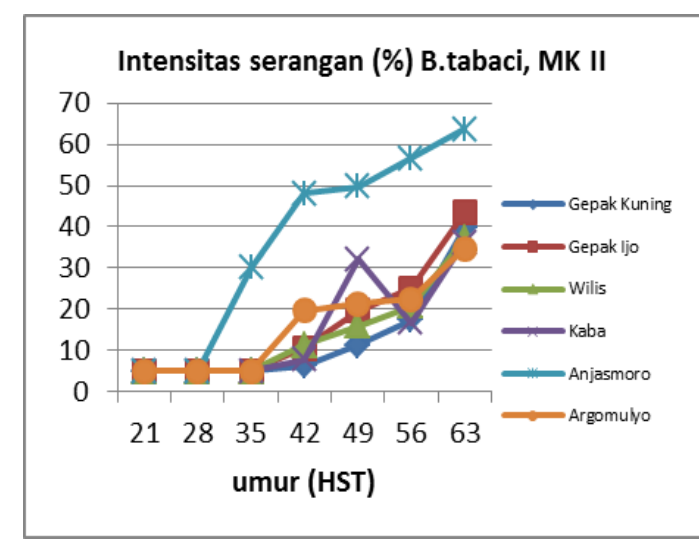

$\mathrm{b}$

Gambar 1. Pengaruh varietas terhadap intensitas serangan Bemisia tabaci pada MK I (a) dan MK II (b), tahun 2010 di KP Muneng, Probolinggo 
I Made Indra Agastya, Reza Prakoso Dwi Julianto dan Marwoto / Buana Sains Vol 20 No 1 : 99-110

Tabel 1. Keragaman toleransi varietas terhadap serangga hama kutu kebul B. tabaci.

\begin{tabular}{clcc}
\hline No & \multicolumn{1}{c}{ Varietas } & \multicolumn{2}{c}{ Hasil ton/ha } \\
& & & Disemprot Insektisida \\
& & 1,56 & Tanpa Insektisida \\
\hline 1 & Gepak Kuning & 1,46 & 1,07 \\
2 & Gepak Hijau & 1,77 & 1,05 \\
3 & Wilis & 1,70 & 1,09 \\
4 & Kaba & 0,12 & 0,93 \\
5 & Anjasmoro & 1,77 & 0,04 \\
6 & Argomulyo & & 0,86 \\
\hline
\end{tabular}

Sumber. Marwoto (2007)

Pada kondisi serangan kutu kebul yang cukup berat varietas Anjasmoro pada perlakuan tanaman disemprot dengan insektisida hanya menghasilkan biji kering panen 0,04 ton/ha dan tanpa pengendalian dengan insektisida hanya 0,04 ton/ha, sedang varietas unggul yang lain Gepak Kuning, Gepak Ijo, Wilis, Kaba dan Argomulyo yang di semprot maupun tidak disemprot dengan insektisida mampu menghasilkan biji kedelai di atas 1 ton/ha Tabel 1.

\section{Dampak Pemanasan Global Terhadap Populasi Hama}

Pemanasan global menyebabkan perubahan iklim dan kenaikan frekuensi maupun intensitas kejadian cuaca ekstrim. Perubahan iklim tersebut mendorong peningkatan suhu bumi yang telah dan akan merubah kondisi iklim global, regional dan lokal. Perubahan iklim diyakini akan berdampak terhadap berbagai aspek kehidupan dan sektor pembangunan, terutama sektor pertanian, dan dikuatirkan akan mendatangkan masalah baru bagi keberlanjutan produksi pertanian, terutama tanaman pangan (Irianto, 2009). Pemanasan global dapat menyebabkan perubahan yang signifikan dalam sistem fisik dan biologis seperti peningkatan intensitas badai tropis, perubahan pola presipitasi, salinitas air laut, perubahan pola angin, masa reproduksi hewan dan tanaman, distribusi spesies dan ukuran populasi, frekuensi serangan hama dan wabah penyakit (Witular, 2008).

Berdasarkan hasil pemantauan akibat pemanasan global yang paling berpengaruh terhadap produksi tanaman antara lain adalah : kekeringan, penurunan/peningkatan curah hujan dan peningkatan suhu udara. Penurunan curah hujan akibat variabilitas iklim maupun perubahan musiman disertai dengan peningkatan temperatur telah menimbulkan dampak yang signifikan terhadap ekosistem pertanian (kekeringan/ketersediaan air terbatas, menurun/meningkatnya curah hujan, gangguan hama dan penyakit tanaman).

Tanda-tanda di lapangan menunjukkan kaitan kuat antara masalah hama dan penyakit dengan perubahan iklim yang terjadi. Temperatur merupakan faktor utama yang berperan dalam perubahan iklim global dan secara langsung berpengaruh terhadap serangga hama (Bale et al., 2002). Beberapa pakar 
telah meramalkan bahwa pengaruh pemanasan global akan menyebabkan peningkatan intensitas serangan hama pada tanaman (Cannon, 1998; Coley, 1998; Wilf dan Labandeira, 1999; Bale et al., 2002). Hasil penelitian Adler et al., (2007) menyatakan bahwa pemanasan meningkatkan kepadatan populasi aphis di lapang.

Beberapa perubahan iklim global di Indonesia, terkait dengan peningkatan dan penurunan serangan hama maupun penyakit. Thrips merupakan hama yang akhir-akhir ini makin merusak. Kemarau tahun 2006, hama kutu kebul Bemisia tabaci menimbulkan kerugian besar pada usaha tani kedelai di Lamongan, Gresik dan Bojonegoro. Saat itu populasi hama sangat tinggi dan tingkat kerusakan yang ditimbulkannya berat. Di lapangan tidak ada satu pestisida sintetispun yang efektif mengendalikannya. Populasi kutu daun bisa meledak bila kemarau semakin kering dan suhu rata-rata semakin panas (Surya Wiyono, 2009).

Pengaruh kenaikan suhu terhadap perkembangan dan pertumbuhan serangga hama dalam kondisi lingkungan suhu optimum, adalah kecepatan proses metabolisme serangga hama akan meningkat berbanding lurus dengan kenaikan suhu lingkungan. Hal ini berarti bahwa apabila suhu naik, proses metabolisme serangga bertambah cepat. Proses metabolisme di dalam tubuh serangga hama merupakan fenomena-fenomena fisio kimia yang serba komplek, proses ini menentukan kecepatan tumbuh maupun berkembangnya suatu organisme. Apabila metabolisme berlangsung cepat, maka perkembangan serangga hamapun semakin meningkat. Waktu yang dibutuhkan serangga hama untuk berkembang berbanding terbalik dengan suhu : suhu meningkat, proses metabolisme makin cepat dan waktu yang dibutuhkan untuk menyelesaikan perkembangan serangga semakin cepat. Bellotti (1990) melaporkan bahwa perkembangan tungau merah pada tanaman kedelai mulai dari telur sampai imago sangat dipengaruhi oleh suhu udara. Waktu perkembangan tungau $\mathrm{T}$. urticae di laboratorium pada suhu $15^{\circ} \mathrm{C}, 20^{\circ} \mathrm{C}$, $25^{\circ} \mathrm{C}$ dan $30^{\circ} \mathrm{C}$ masing-masing sekitar 30, 16, 8 dan 7 hari. (Stafford, 2008).

Pengaruh suhu pada aktivitas terbang serangga hama sangat nyata, efek yang dihasilkan adalah sangat besar, walaupun perbedaan itu hanya beberapa derajad saja. Dalam kondisi optimum untuk pertumbuhan serangga hama, adanya kenaikan suhu akan memicu aktivitas terbang serangga hama. Suhu juga berpengaruh terhadap pembiakan serangga hama, dalam kondisikondisi tertentu umur kedewasaan kelamin memendek dengan naiknya suhu. Di dalam alam terbuka, persyaratan suhu yang dibutuhkan oleh serangga untuk mengadakan aktivitas seksual kebanyakan berhubungan dengan cahaya, lengas dan faktor iklim yang lain, terutama cahaya yang ikut memegang peranan penting. Hujan berpengaruh terhadap perkembangan dan aktivitas serangga hama. Efek mekanis hujan merupakan pengaruh yang langsung. Hujan yang lebat akan menghanyutkan sebagian besar dari populasi jenis serangga-serangga kecil dan lemah seperti kutu-kutu 
daun (tungau, aphis, dan kutu kebul). Populasi hama kutu kebul Bemisia tabaci pada tanaman kedelai rendah pada musim hujan dan meningkat pada kedelai yang ditanam pada musim kemarau (Marwoto et al., 2008). Populasi-populasi hama kutu daun termasuk kutu kebul akan meningkat pada musim kering dengan suhu yang tinggi, dan lengas udara yang rendah.

Suatu ekosistem banyak mekanisme alami yang bekerja secara efektif dan efisien dalam menjaga kelestarian dan keseimbangan ekologi yang dapat menekan populasi suatu hama. Mekanisme-mekanisme alami tersebut adalah faktor biofisik (iklim) dan faktor biologis (predatisme, parasitisme, patogenitas, persaingan intra/inter spesies, suksesi, produktivitas dan stabilitas) (Untung, 2006). Jaring-jaring makanan merupakan unsur ekosistem yang cukup penting dalam pengelolaan hama. Kedudukan usahatani kedelai dalam pola tanam di lahan sawah merupakan tanaman ke dua setelah padi atau ke tiga setelah padi yang jatuh pada musim kemarau/panas. Pola tanam yang biasa dipraktekkan petani adalah : padi - padi - kedelai, padi - jagung - kedelai atau padi kedelai untuk daerah tadah hujan atau pengairan terbatas. Faktor pemicu hama kedelai yang sering menjadi masalah dalam kaitannya dengan isu pemanasan global adalah : a) pertanaman kedelai musim ke tiga (Musim Kemarau II) yang biasanya ekosistem lahan kurang air dan suhu meningkat, oleh karena itu umumnya serangan hama lebih besar. b) sistem tanam tidak serentak dalam satu areal yang luas sehingga tanaman yang terlambat tanam akan menderita kekurangan air, suhu tinggi dan populasi hama penyakit menjadi lebih meningkat. c) cuaca yang panas mendorong peningkatan populasi hama (Marwoto, 2007).

Proses perubahan iklim merupakan proses alami yang merupakan kecenderungan yang terus menerus dan jangka panjang. Oleh sebab itu, strategi antisipasi dan menyiapkan teknologi adaptasi merupakan aspek kunci yang harus dipersiapkan secara matang menjadi Rencana Strategik Departemen Pertanian dalam rangka menyikapi perubahan iklim (Irianto, 2009). Dalam rangka menerapkan konsep Pengendalian Hama Terpadu (PHT) maka perlu dipertimbangkan secara matang, agar kondisi lingkungan dan cara tanam dapat diatur sedemikian rupa sehingga tidak sesuai untuk pertumbuhan dan perkembangan hama.

\section{Upaya Pengendalian Hama Kutu Kebul Pada Tanaman Kedelai}

Komponen-komponen dalam pengendalian hama kedelai yang dapat dipadukan dalam penerapan PHT pada tanaman kedelai dalam rangka antisipasi pemanasan global adalah :

\section{Pengendalian alami}

Pengendalian ini merupakan proses pengendalian yang berjalan sendiri tanpa kesengajaan yang dilakukan manusia. Pengendalian alami terjadi tidak hanya karena bekerjanya musuh alami, tetapi juga karena komponen-komponen ekosistem lainnya seperti makanan, dan cuaca. Pemanfaatan pengendalian alami dengan mengurangi tindakan-tindakan yang dapat merugikan atau mematikan perkembangan musuh alami dapat 
dilakukan seperti tumpangsari untuk merakit ekosistem yang keragamannya tinggi, tanaman perangkap yang disukai untuk berlindung musuh alami (tanaman kacang hijau di hamparan kedelai merupakan terminal untuk untuk berteduh musuh alami). Hindari aplikasi insektisida berspektrum luas, sehingga tidak mematikan musuh alami di ekosistem kedelai. Menurut Huffaker et al. (1971) pengendalian alami disebut juga sebagai keseimbangan alami (balance of nature) yaitu penjagaan jumlah populasi suatu organisme dalam kisaran batas atas dan batas bawah tertentu sebagai hasil tindakan pengelolaan lingkungan keseluruhan baik lingkungan biotik maupun abiotik. Sampai tingkatan tertentu pengendalian alami tentu berpengaruh terhadap semua jenis organisme. Pengertian ini menekankan bahwa populasi hama dalam kurun waktu tertentu dan pada kombinasi komponen-komponen ekosistem tertentu berada pada suatu keadaan keseimbangan yang dinamik.

\section{Pengendalian fisik dan mekanik}

Tindakan yang kita lakukan dengan tujuan secara langsung dan tidak langsung 1) mematikan hama untuk mengurangi populasi hama, 2) mengganggu aktivitas fisiologis hama yang normal, dan 3) mengubah lingkungan fisik menjadi kurang sesuai bagi kehidupan dan perkembangan hama. Perbedaan pengendalian fisik dan mekanik dengan pengendalian secara budidaya adalah pada pengendalian fisik dan mekanik, tindakan ini mengubah lingkungan yang ditujukan khusus untuk mematikan atau menghambat kehidupan hama dan bukan merupakan praktek budidaya yang umum. Pengurangan populasi hama/penyakit dengan cara fisik mekanik dapat dilakukan dengan mengambil kelompok telur dan membunuh larva hama atau imagonya atau mengambil tanaman yang sakit. Pengendalian secara fisik dan mekanik harus dilandasi oleh pengetahuan yang menyeluruh tentang ekologi serangga hama dan adanya kenyataan bahwa setiap jenis serangga memiliki batas toleransi terhadap faktor lingkungan fisik seperti suhu, kelembaban, bunyi, sinar, spektrum elektromagnitik dll. Dengan mengetahui ekologi serangga hama sasaran kita dapat mengetahui kapan, di mana, dan bagaimana tindakan fisik dan mekanik kita lakukan agar diperoleh hasil seefektif dan seefisien mungkin. Penanaman kedelai musim kemarau, yang ekosistemnya lebih panas dari pada musim hujan dapat diramalkan bahwa populasi hama, khususnya kutu kebul populasinya akan meningkat. Oleh karena itu pada penanaman kedelai pada musim kemarau, perlu tindakan mekanis dengan pemasangan trap kuning, atau dengan penjaringan/sweeping untuk mengurangi populasi hama kutu kebul.

3. Pengendalian secara budidaya Pengendalian preventif, dilakukan sebelum serangan hama terjadi dengan sasaran agar populasi tidak meningkat sampai melebihi ambang kendalinya. Agar hasilnya memuaskan penerapan teknik ini perlu direncanakan sebelumnya. Untuk meningkatkan efektivitas dan efisiensi pengendalian secara bercocok tanam perlu dipadukan dengan teknik-teknik pengendalian hama lainnya sesuai dengan prinsipprinsip PHT. Karena teknik 
pengendalian ini merupakan bagian teknik budidaya tanaman yang umum dalam pelaksanaannya, petani tidak perlu mengeluarkan biaya khusus untuk pengendalian hama. Dengan demikian teknik pengendalian ini merupakan teknik pengendalian yang murah, pengendalian ini tidak menyebabkan pencemaran lingkungan, dan mudah dikerjakan oleh petani perseorangan maupun kelompok. Untuk mengembangkan teknik pengendalian hama ini diperlukan pengetahuan sifat-sifat ekosistem setempat khususnya tentang ekologi dan perilaku hama seperti tentang bagaimana hama memperoleh berbagai persyaratan bagi kehidupannya termasuk makanan, perkawinan, dan tempat persembunyian untuk menghindarkan serangan cuaca buruk dan berbagai musuh alami Untung, 2006). Dari pengetahuan biologi dan ekologi hama, kita dapat mengerti tentang titik lemah hama sehingga dapat diketahui fase hidup hama yang paling tepat untuk dilakukan pengendalian. Menurut Pedigo (1996), sebagian besar teknik pegendalian hama secara budidaya dapat dikelompokkan menjadi empat sesuai dengan sasaran yang akan dicapai yaitu : 1) Mengurangi kesesuaian ekosistem dengan penanaman kedelai lebih awal pada akhir musim hujan, 2) mengganggu kontinuitas penyediaan penyediaan keperluan hidup hama, 3) mengalihkan populasi hama menjauhi tanaman, dan 4) mengurangi dampak kerusakan tanaman.

Upaya antisipasi peledakan populasi hama pada tanaman kedelai akibat pemanasan global dengan teknik budidaya dapat dilakukan dengan cara : a. Penanaman kedelai umur genjah, seperti varietas Grobogan, Malabar dan Tidar yang mempunyai umur panen sekitar 74 - 78 hari (Suhartina, 2008), merupakan salah satu usaha untuk memperpendek umur tanaman terserang hama, mengurangi kesesuaian ekosistem dan mengganggu penyediaan makanan atau keperluan hidup hama.

b. Penggunaan varietas tahan hama seperti : Penanaman varietas toleran terhadap kutu kebul seperti Detam 1, Detam 2, Wilis, Gepak Kuning, Gepak ijo, Kaba, dan Argomulyo. Untuk daerah endemis kutu kebul tidak disarankan menanam varietas Anjasmoro. Pada kondisi populasi kutu kebul tinggi perlu dibantu dengan aplikasi insektisida. Penanaman varietas toleran hama merupakan usaha teknik budidaya untuk mengurangi dampak kerusakan tanaman dan mengurangi kesesuaian ekosistem hama.

c. Rotasi tanaman atau pergiliran tanaman antara kedelai-padi atau dengan tanaman bukan kacangkacangan dapat memutus siklus hama dan dapat menekan populasi hama kutu kedelai (Bemisia tabaci).

d. Tumpangsari kedelai dengan jagung merupakan upaya untuk mengendalikan hama pada tanaman kedelai, tanaman jagung pada tanaman kedelai dapat berperan sebagai tanaman penghalang dari distribusi dan penyebaran hama di area pertanaman kedelai. Populasi hama Bemisia tabaci pada tumpangsari kedelai+jagung populasinya menurun dibanding pada tanaman monokultur kedelai. Jagung pada tanaman tumpangsari dengan kedelai, disamping sebagai tanaman penghalang distribusi dan 
penyebaran juga dapat sebagai tanaman perangkap. Penanaman tanaman penghalang atau penolak dengan tujuan menghambat penerbangan/migrasi hama, misalnya: penanaman jagung pada areal pertanaman kedelai untuk menghalangi atau mengganggu migrasi hama kutu kebul (Marwoto et al., 1991). Tanaman penghalang (barier) dengan tanaman jagung yang rapat dapat membantu mengurangi migrasi kutu kebul.

\section{Pengendalian dengan kimiawi}

Penggunaan pestisida kimiawi secara selektif dengan tujuan untuk mengembalikan populasi hama pada aras keseimbangannya. Keputusan tentang penggunaan pestisida dilakukan setelah diadakan analisis ekosistem terhadap hasil pengamatan dan ketetapan tentang ambang kendali. Pestisida yang dipilih harus yang efektif dan telah diizinkan.

\section{Pengendalian Hama Terpadu}

Pengendalian hama pada tanaman kedelai berlandaskan strategi penerapan Pengendalian Hama Terpadu (PHT). PHT adalah suatu cara pendekatan atau cara pengendalian hama yang didasarkan pada pertimbangan ekologi dan efisiensi ekonomi dalam rangka pengelolaan ekosistem yang berwawasan lingkungan yang berkelanjutan. Strategi penerapan PHT untuk menghadapi dampak pemanasan global perlu dilandasi oleh informasi dasar tentang agroekosistem maupun sistem sosial ekonomi setempat. Perpaduan teknik atau taktik komponen teknologi pengendalian hama kedelai yang optimal ditetapkan atas dasar pengetahuan informasi yang tepat tentang hama kedelai, ekosistem dan sosial ekonomi.

\section{Kesimpulan}

Dari uraian dampak pemanasan global terhadap peningkatan populasi dan intensitas serangan hama kutu kebul pada tanaman kedelai di atas maka dapat ditarik kesimpulan sebagai berikut :

1. Salah satu dampak perubahan iklim global adalah meningkatnya populasi hama pada tanaman pertanian. Tanaman kedelai di negara tropis termasuk Indonesia mempunyai kompleksitas hama yang beragam, dengan adanya peningkatan suhu di bumi akan berakibat juga meningkatnya populasi hama kutu kebul pada tanaman kedelai.

2. Salah satu kendala utama dalam peningkatan produksi kedelai adalah karena gangguan hama. Kerugian akibat serangan hama kutu kebul pada tanaman kedelai dapat menurunkan hasil sampai $80 \%$, bahkan puso apabila tidak ada tindakan pengendalian.

3. Hama kutu daun Bemisia tabaci populasinya meningkat akibat kenaikkan suhu udara, udara panas akan memicu proses metabolisme meningkat, yang berakibat memperpendek siklus hidup dan jumlah telur akan meningkat. Dengan meningkatnya hama kutu kebul pada tanaman kedelai berakibat populasi dan intensitas serangan meningkat dan kehilangan hasil kedelai semakin tinggi bahkan puso.

4. Upaya untuk mengatasi dampak pemanasan global terutama akibat meningkatnya populasi hama maka diperlukan pemikiran dan 
mencari terobosan-terobosan untuk antisipasi meledaknya populasi hama pada tanaman kedelai antara lain dengan : optimalisasi pengendalian alami, pengendalian fisik dan mekanik serta teknik bercocok tanam. Perpaduan teknik atau taktik komponen teknologi pengendalian hama kedelai yang optimal ditetapkan atas dasar pengetahuan informasi yang tepat tentang hama kedelai, ekosistem dan sosial ekonomi berlandaskan pendekatan PHT.

\section{Daftar Pustaka}

Adler, L.S, P. D. Valpine, J. Harte, and J. Call. 2007. Effects of Long-term Experimental Warming on Aphid Density in the Field. Journal of the Kansas Entomological Society 80(2), 2007, Pp. 156-168

Bale, J. S., G. J. Masters, I. D. Hodkinson, C. Awmack, T. M. Bezemer, V. K. Brown, J. Butterfield, A. Buse, J. C. Coulson, J. Farrar, J. E. G. Good, R. Harrington, S. Hartley, T. H. Jones, R. L. Lindroth, M. C. Press, I. Symrnioudis, A. D. Watt, and J. B. Whittaker. 2002. Herbivory in global climate change research: direct effects of rising temperature on insect herbivores. Global Change Biology 8:1-16.

Bellotti, A.C. 1990. A review of control strategies for four important cassava pests in the Americas. Dalam Hahn, S.K., F.E. Caveness (Eds). Integrated pest management for tropical root and tuber crops. IITA. p.58-65.
Cannon, R. J. C. 1998. The implications of predicted climate change for insect pests in the UK, with emphasis on non-indigenous species. Global Change Biology 4:785-796.

Coley, P. D. 1998. Possible effects of climate change on plant/herbivore interactions in moist tropical forests. Climatic Change 39:455-472.

Huffaker,C.B., P.S. Mesenger, dan P. de Bach .1971. The Natural Enemy Component in Natural Control and The Theory of Biological Control. Dalam C.B. Huffaker dan P.S. Mesenger (ed). Theory and Practice of Biology Control. Academic Press. New York. 788 p.

Irianto, S.G. 2009. Perubahan Iklim dan Ketahanan Pangan : Dampak dan Strategi serta Antisipasinya. Pemanasan Global : Strategi Mitigasi dan Adaptasi Perubahan Iklim di Indonesia. Seminar Nasional Fak. Pertanian. Univ. Brawijaya. Malang 31 Januari 2009. 14 hal.

Hirano, K., Budiyanto, E. and Winarn, S. 1993. Biological characteristics and forecasting outbreaks of the whitefly Bemisia tabaci, a vector of virus diseases in soybean fields. Food and Fertilizer Technology Center (FFTC). pp. 13

Hirano, K., E. Budiyanto, and S. Winarni. 2002. Biological characteristics and forecasting outbreaks of the whitefly, Bemisia tabaci, a vector of virus diseases in soy beanbean fileds. An International Information 
Center for Farmers in the Asia Pasific Region. 10 p.

Inayati, A. dan Marwoto. 2012. Pengaruh kombinasi aplikasi insektisida dan varietas unggul terhadap intensitas serangan kutu kebul dan hasil kedelai. Jurnal Penelitian Pertanian. Tanaman Pangan 31 (1) :13-21.

Marwoto., E. Wahyuni, dan K. E. Neering. 1991. Pengelolaan Pestisida dalam Pengendalian Hama Kedelai Secara Terpadu. Monograf Balittan Malang 7:39.

Marwoto., S. Hardaningsih, dan A. Taufik. 2008. Hama, Penyakit dan Masalah Hara pada tanaman kedelai. Identifikasi dan Pengendaliannya. Puslitbangtan. 66 hal.

Marwoto. 2010. Teknologi Pengendalian hama kutu kebul Bemisia tabaci pada produksi kedelai di lahan optimal untuk menekan kehilangan hasil sebesar 30\%. Laporan Penelitian Balitkabi 2010. 30 hal.

Pedigo,L.P. 1996. Entomology and Pest Management. Second Edition. Prentice Hall Inc. USA. 679 p.

Stafford, K.C., III. 2008. Fly management handbook A guide to biology, dispersal, And management of the house Fly and related flies for Farmers, municipalities, and Public health officials Connecticut Agricultural Experiment Station, New Haven. Bulletin 1013. May 2008. 40 p.

Suryo Wiyono. 2009. Perubahan iklim, pemicu ledakan hama dan penyakit tanaman. Salam, 26 Januari 2009. Hal : 22-23.
Tengkano, W., dan M. Suhardjan, 1985. Jenis hama utama pada berbagai fase pertumbuhan tanaman kedelai. Dalam Sadikin, S., M. Ismunadji, Sumarno, M. Syam, S.O. Manurung, Yuswadi (eds). Kedelai. Puslitbangtan, Bogor. Hlm. 295-318.

Untung, K. 2006. Pengantar Pengelolaan Hama Terpadu (Edisi kedua). Gadjah Mada University Press. 348 hal.

Wilf, P., and C. C. Labandeira. 1999. Response of plant-insect associations to Paleocene-Eocene warming. Science 284:2153-2156.

Saleh, N dan S. Hardaningsih. 2007. Pengendalian penyakit terpadu pada tanaman kedelai. Kedelai. Teknologi dan Pengembangan. Puslitbangtan. Hal: 319-344.

Tengkano, W., dan M. Suhardjan, 1985. Jenis hama utama pada berbagai fase pertumbuhan tanaman kedelai. Dalam Sadikin, S., M. Ismunadji, Sumarno, M. Syam, S.O. Manurung, Yuswadi (eds). Kedelai. Puslitbangtan, Bogor. Hlm. 295-318. 
I Made Indra Agastya, Reza Prakoso Dwi Julianto dan Marwoto / Buana Sains Vol 20 No 1 : 99-110 